\title{
Differential interaction of glimepiride and glibenclamide with the $\beta$-cell sulfonylurea receptor I. Binding characteristics
}

\author{
Günter Müller *, Detlev Hartz, Jürgen Pünter, Raymond Ökonomopulos, Werner Kramer \\ Hoechst AG Frankfurt am Main, Pharmaceutical Research Divison, SBU Metabolic Diseases H 825, P.O. Box 800320, \\ D-65926 Frankfurt am Main, Germany
}

(Received 18 May 1993; revised manuscript received 10 December 1993)

\begin{abstract}
Glimepiride is a novel sulfonylurea drug for treatment of non-insulin-dependent diabetes mellitus with higher blood sugar lowering efficacy in diabetic patients than glibenclamide raising the question whether this characteristics is in line with different binding of glimepiride and glibenclamide to the $\beta$-cell sulfonylurea receptor. Scatchard plot analysis of $\left[{ }^{3} \mathrm{H}\right]$ sulfonylurea binding to membranes isolated from rat $\beta$-cell tumors and (RINm5F) insulinoma cells and to RINm5F cells demonstrated that glimepiride has a $2.5-3$-fold lower affinity than glibenclamide. This corresponded well to the 8-9-fold higher $k_{\text {off }}$ and 2.5 -3-fold higher $k_{\text {on }}$ rates of glimepiride compared to glibenclamide as revealed by the dissociation and association kinetics of $\left[{ }^{3} \mathrm{H}\right]$ sulfonylurea binding and the $K_{\mathrm{d}}$ values calculated thereof. In agreement, the concentrations required for half-maximal displacement of $\left[{ }^{3} \mathrm{H}\right]$ sulfonylurea bound to $\beta$-cell membranes were significantly higher for glimepiride compared to glibenclamide. However, the binding affinity of glimepiride measured by both equilibrium binding and kinetic binding studies upon solubilization of $\beta$-cell tumor membranes and RINm5F cell membranes increased up to the value for glibenclamide. This was primarily based on a drastic decrease of the dissociation rate constant of glimepiride whereas the kinetics of glibenclamide binding remained largely unaffected upon solubilization. These data suggest that the $K_{\mathrm{d}}$ value alone is not sufficient for characterization of a sulfonylurea drug, since the kinetic binding parameters may also determine its acute blood sugar lowering efficacy.
\end{abstract}

Key words: Sulfonylurea receptor; Sulfonylurea binding kinetics; Glimepiride; Glibenclamide; Insulin secretion; Beta cell

\section{Introduction}

Sulfonylurea drugs are widely used in the therapy of NIDDM. The initial hypoglycemic effect of oral sulfonylurea administration appears to rely on the acute stimulation of-the rate of insulin release from the pancreas (Yalow et al. [1]). At the molecular level sulfonylureas are proposed to stimulate insulin secretion by binding to a receptor protein of the plasma membrane of pancreatic $\beta$-cells (for reviews, see $[2,3]$ ). Receptor occupancy has been shown to inhibit $\mathrm{K}^{+}$-efflux via a plasma membrane ATP-regulated $\mathrm{K}^{+}$-chan-

\footnotetext{
* Corresponding author. Fax: +4969311454 .

Abbreviations: NIDDM, non-insulin-dependent diabetes mellitus; RINm5F cells, rat insulinoma cells; PEG, poly(ethylene glycol).
}

nel in islet cells [4] and $\beta$-cell lines such as RINm5F [5] or HIT T15 [6]. These channels also participate in the control of insulin release by glucose [7] via changes in the intracellular [ATP]/[ADP] ratio. Subsequent depolarization of the plasma membrane causes opening of voltage-dependent $\mathrm{Ca}^{2+}$-channels. The rise in intracellular $\mathrm{Ca}^{2+}$ triggers insulin release $[8,9]$ (for a review, see [10]). This chain of events couples the insulin releasing effect and, thus, the primary hypoglycemic capacity of sulfonylureas via the plasma membrane electrical activity to their affinity to the $\beta$-cell sulfonylurea binding sites which control the open/closed probability of the ATP-regulated $\mathrm{K}^{+}$-channel by unknown mechanisms.

Specific high-affinity binding sites (for a recent review, see Ashcroft and Ashcroft [11]) have been characterized previously in $\beta$-cell tumor membranes [12- 
14], RINm5F cell membranes and intact RINm5F cells [15], mouse pancreatic islet microsomes [16], hamster insulin-secreting tumor cell (HIT T15) membranes [14,17,18] and intact HIT T15 cells [19]. In fact, a direct correlation has been found for the sulfonylureas studied so far between their dissociation constants for binding to $\beta$-cell membranes and their ability to induce insulin secretion and to lower the blood sugar $[5,13,16]$. For instance, the second generation sulfonylurea, glibenclamide, is a 1000 -fold more potent stimulator of insulin secretion than first generation compounds such as tolbutamide in correlation with the 1000-10000-fold lower $K_{\mathrm{d}}$ value of glibenclamide compared to tolbutamide [5]. Using the receptor occupancy theory, it was successful to predict the therapeutic blood concentrations and usual doses of sulfonylureas, based on the good correlation between plasma unbound concentration, insulin releasing potency and $K_{\mathrm{d}}$ values [20].

The novel sulfonylurea drug, glimepiride, is characterized by a $2-3$-fold higher efficacy in diabetic patients compared to glibenclamide with respect to equivalence of the dose ranges leading to identical blood sugar levels after oral administration (Draeger, E., unpublished results). Here we studied whether glimepiride exhibits higher binding affinity to the $\beta$-cell sulfonylurea receptor than glibenclamide and found that, in contradiction to this expectation, other (kinetic) binding parameters may explain the lower therapeutic doses required with glimepiride.

Parts of the results have been published in abstract form:

Kramer, W., Ökonomopulos, R., Pünter, J. and Summ, H.-D. (1992) Diabetologia 35 (Suppl. 1), A 38;

Müller, G., Hartz, D., Pünter, J., Ökonomopulos, R., Summ, H.-D. and Kramer, W. (1993) International Conference on ATP-sensitive $\mathrm{K}^{+}$-channels and sulfonylurea receptors, Houston, TX, Book of Abstracts, p. 158.

\section{Materials and methods}

Materials. Glimepiride (HOE 490), glibenclamide (HB 419), tolbutamide, $\left[{ }^{3} \mathrm{H}\right]$ glimepiride $(65 \mathrm{Ci} / \mathrm{mmol})$ and $\left[{ }^{3} \mathrm{H}\right]$ glibenclamide $(33 \mathrm{Ci} / \mathrm{mmol})$ were synthesized at Hoechst AG, Frankfurt, Germany [13,21]. A $10 \mathrm{mM}$ stock solution of glimepiride (made daily) was prepared by suspending $9.95 \mathrm{mg}$ of glimepiride in $1.94 \mathrm{ml}$ aqua bidest., subsequent supplementation of $60 \mu \mathrm{l}$ of 1 $\mathrm{M} \mathrm{NaOH}$ and warming up to $50-70^{\circ} \mathrm{C}$. This solution was either added directly (up to $1: 200$ dilution) to the buffered assay mixtures containing membranes or cells. Radiolabeled sulfonylureas were diluted with $25 \mathrm{mM}$ Hepes-KOH (pH 7.8). Scintillation cocktail ACS II was provided by Amersham-Buchler, Braunschweig, Germany. Collagenase, trypsin and proteinase inhibitors were from Boehringer, Mannheim, Germany. BSA (fraction V, radioimmunoassay grade), RPMI-1640 medium, fetal calf serum and antibiotics were obtained from Sigma, Deisenhofen, Germany. All other reagents (analytical grade) were provided from Merck, Darmstadt, Germany. Petri dishes and culture flasks were purchased from Nunc, Roskilde, Denmark. Glass fiber filters were from Whatman, Maidstone, UK. Nitrocellulose filters were bought from Millipore, Eschborn, Germany. Rats of the strain NEDH (New England Deaconess Hospital) were kindly donated by S. Warren.

Cell culture. RINm5F cells of the insulin-producing cell line, derived from a rat islet cell tumor [22,23], were grown in RPMI-1640 medium containing $10 \%$ $(\mathrm{v} / \mathrm{v})$ heat-inactivated fetal calf serum, $50 \mathrm{IU} / \mathrm{ml}$ penicillin, $0.25 \mu \mathrm{g} / \mathrm{ml}$ fungizone and $50 \mu \mathrm{g} / \mathrm{ml}$ streptomycin at $37^{\circ} \mathrm{C}$ in an atmosphere of humified air $/ \mathrm{CO}_{2}$ (19:1) according to Praz et al. [24] with the following modifications: The cells were seeded at a density of $(2-4) \cdot 10^{4}$ cells $/ \mathrm{ml}$ in $20 \mathrm{ml}$ of medium $\left(75 \mathrm{~cm}^{2}\right.$ culture flasks). The medium was replaced four times per week (one passage). Thereafter, the cells were treated with trypsin $(0.02 \%$ trypsin in $0.9 \% \mathrm{NaCl} / 0.2 \mathrm{mM}$ EDTA) for $2-5 \mathrm{~min}$ at $37^{\circ} \mathrm{C}$. The trypsin-treated cells were diluted, reseeded at a density of $2 \cdot 10^{6}$ cells per $75 \mathrm{~cm}^{2}$ culture flask and grown to $70 \%$ confluency.

Preparation of RINm5F cell membranes. Cells from one culture flask were washed twice with ice-cold 25 $\mathrm{mM}$ Hepes- $\mathrm{KOH}$ (pH 7.4), $0.25 \mathrm{M}$ sucrose, $0.5 \mathrm{mM}$ EDTA, scraped with $20 \mathrm{ml}$ of the same buffer and homogenized with 10 strokes of a tight fitting PotterElvehjem homogenizer followed by sonication (bath sonicator, $4^{\circ} \mathrm{C}, 10 \mathrm{~s}$, maximal power). After centrifugation $\left(200000 \times g, 45 \mathrm{~min}, 4^{\circ} \mathrm{C}\right)$, the pellet was suspended in $10 \mathrm{ml}$ of $25 \mathrm{mM}$ Hepes-KOH (pH 7.4), 0.25 $M$ sucrose, $100 \mathrm{mM} \mathrm{NaCl}, 0.5 \mathrm{mM}$ EDTA, $200 \mu \mathrm{M}$ PMSF and recentrifuged $(1000 \times g, 10 \mathrm{~min})$. The supernatant was transferred to a new tube and centrifuged $\left(50000 \times \mathrm{g}, 30 \mathrm{~min}, 4^{\circ} \mathrm{C}\right)$. The pellet was washed once with $25 \mathrm{mM}$ Hepes- $\mathrm{KOH}$ ( $\mathrm{pH} 7.4$ ), 0.25 $M$ sucrose and finally suspended in membrane buffer (25 mM Hepes-KOH (pH 7.4), $0.25 \mathrm{M}$ sucrose, 150 $\mathrm{mM} \mathrm{NaCl}, 1 \mathrm{mM}$ EDTA, $100 \mu \mathrm{M}$ PMSF, $10 \mu \mathrm{g} / \mathrm{ml}$ soybean trypsin inhibitor, $10 \mu \mathrm{M}$ leupeptin, $10 \mu \mathrm{M}$ pepstatin, $20 \mu \mathrm{g} / \mathrm{ml} \mathrm{E}-64,1 \mathrm{mM}$ iodoacetamide) at 5 $\mathrm{mg}$ protein $/ \mathrm{ml}$. Aliquots were frozen in liquid $\mathrm{N}_{2}$ and stored at $-80^{\circ} \mathrm{C}$.

Preparation of $\beta$-cell tumor membranes. Non-malignant $\beta$-cell adenoma tissue was dissected from rats of the strain NEDH after several transplantation cycles of the insulinoma when the tumor has grown up to a diameter of $2-3 \mathrm{~cm}$ as described previously (Geisen et al. [13]), homogenized in $50 \mathrm{ml}$ of buffer A $(25 \mathrm{mM}$ Hepes-KOH (pH 7.4), 0.25 M sucrose, $0.5 \mathrm{mM}$ EDTA, $100 \mu \mathrm{M}$ PMSF $)$ per $\mathrm{g}$ tissue in an Ultraturrax $(3 \times 5 \mathrm{~s}$, 
max. power, on ice) and centrifuged $(3000 \times g, 5 \mathrm{~min})$. The supernatant was transferred into new tubes and centrifuged $\left(200000 \times g, 60 \mathrm{~min}, 4^{\circ} \mathrm{C}\right)$. The pellet was washed with $2 \times 5 \mathrm{ml}$ of buffer $A$, resuspended in 10 $\mathrm{ml}$ of buffer A per $\mathrm{g}$ tissue and centrifuged $(75000 \times \mathrm{g}$, $30 \mathrm{~min}$ ). The pellet was suspended in buffer A using a tight-fitting Dounce homogenizer.

Binding of sulfonylureas to $\beta$-cell membranes. Filter binding assays were performed in a total volume of 1 $\mathrm{ml}$ containing the indicated amounts of protein, $25 \mathrm{mM}$ Mops- $\mathrm{KOH}(\mathrm{pH} 7.4), 0.1 \mathrm{mM} \mathrm{CaCl}{ }_{2}$ and $0.1-20 \mathrm{nM}$ $\left[{ }^{3} \mathrm{H}\right]$ sulfonylurea. After incubation $\left(25^{\circ} \mathrm{C}, 60 \mathrm{~min}\right.$ for equilibrium conditions or periods indicated for kinetic experiments), the binding reactions were terminated by rapid filtration through Whatman GF/F filters soaked in the same buffer. The filters were washed with $3 \times 5$ $\mathrm{ml}$ of ice-cold $25 \mathrm{mM}$ Hepes- $\mathrm{KOH}$ (pH 7.4), $100 \mathrm{mM}$ $\mathrm{NaCl}, 1 \mathrm{mM}$ EDTA, $200 \mu \mathrm{M}$ PMSF, $0.5 \mu \mathrm{g} / \mathrm{ml}$ leupeptin, $0.75 \mu \mathrm{g} / \mathrm{ml}$ pepstatin and $2 \times 5 \mathrm{ml}$ of ice-cold Hepes- $\mathrm{KOH}$ (pH 7.4), placed in $10 \mathrm{ml}$ of ACSII scintillation cocktail and after incubation overnight counted for radioactivity in a liquid scintillation counter. Nonspecific binding in parallel samples was determined in the presence of $1 \mu \mathrm{M}$ unlabeled ligand.

Binding of sulfonylureas to solubilized $\beta$-cell membrane proteins. Isolated $\beta$-cell tumor or RINm5F cell membranes were diluted with $25 \mathrm{mM}$ Mops- $\mathrm{KOH}(\mathrm{pH}$ 7.4), $100 \mathrm{mM} \mathrm{NaCl}, 0.1 \mathrm{mM} \mathrm{CaCl}, 200 \mu \mathrm{M}$ PMSF, 0.5 $\mu \mathrm{g} / \mathrm{ml}$ leupeptin, $0.75 \mu \mathrm{g} / \mathrm{ml}$ pepstatin, $50 \mu \mathrm{g} / \mathrm{ml}$ antipain dihydrochloride, $1 \mu \mathrm{g} / \mathrm{ml}$ aprotinin at $1 \mathrm{mg}$ protein $/ \mathrm{ml}$ and solubilized by addition of $1 / 10 \mathrm{vol}$. of $10 \%$ digitonin and subsequent incubation $\left(30 \mathrm{~min}, 4^{\circ} \mathrm{C}\right)$ under gentle stirring. After centrifugation $(200000 \times g$, $30 \mathrm{~min}, 4^{\circ} \mathrm{C}$ ), indicated amounts of protein contained in the supernatant were incubated with radiolabeled ligand in a final volume of $1 \mathrm{ml}$ (as described above). The binding reactions were terminated by the addition of $3 \mathrm{ml}$ of ice-cold 15\% PEG 8000, $25 \mathrm{mM}$ Mops-KOH (pH 7.4), $100 \mathrm{mM} \mathrm{NaCl}, 0.5 \mathrm{mM}$ EDTA, $200 \mu \mathrm{M}$ PMSF. After further incubation $\left(15 \mathrm{~min}, 4^{\circ} \mathrm{C}\right)$, the mixtures were filtered through nitrocellulose filters (Millipore, HAWP, $0.22 \mu \mathrm{m}$ ) soaked with ice-cold $10 \%$ PEG 8000. The filters were washed successively with 5 $\mathrm{ml}$ ice-cold 10\% PEG 8000 and $4 \times 5 \mathrm{ml} 2 \%$ PEG 8000 , dried, placed in $10 \mathrm{ml}$ of ACSII scintillation cocktail and counted for radioactivity. Background radioactivity, which was measured by filtration of binding reactions lacking protein and accounted for up to $0.1 \%$ of the total radioactivity added, was subtracted from the total dpm values. Non-specific binding was determined in the presence of $1 \mu \mathrm{M}$ unlabeled ligand.

Binding of sulfonylureas to RINm5F cells. Cells seeded in $75 \mathrm{ml}$ culture flasks at a density of $2 \cdot 10^{6}$ cells and grown to $70 \%$ confluency were treated with trypsin/EDTA (see above), washed with $3 \times 10 \mathrm{ml}$ Hepes-based Krebs-Ringer buffer containing $20 \mathrm{mM}$
Hepes- $\mathrm{KOH}(\mathrm{pH} 7.4), 125 \mathrm{mM} \mathrm{NaCl}, 5 \mathrm{mM} \mathrm{KCl}, 7.5$ $\mathrm{mM} \mathrm{NaHCO}, 2 \mathrm{mM} \mathrm{CaCl} 2,0.8 \mathrm{mM} \mathrm{MgSO}_{4}$ suspended at a density of $2 \cdot 10^{7}$ cells $/ \mathrm{ml}$ in the same buffer and then incubated $\left(4^{\circ} \mathrm{C}, 60 \mathrm{~min}\right.$ for equilibrium
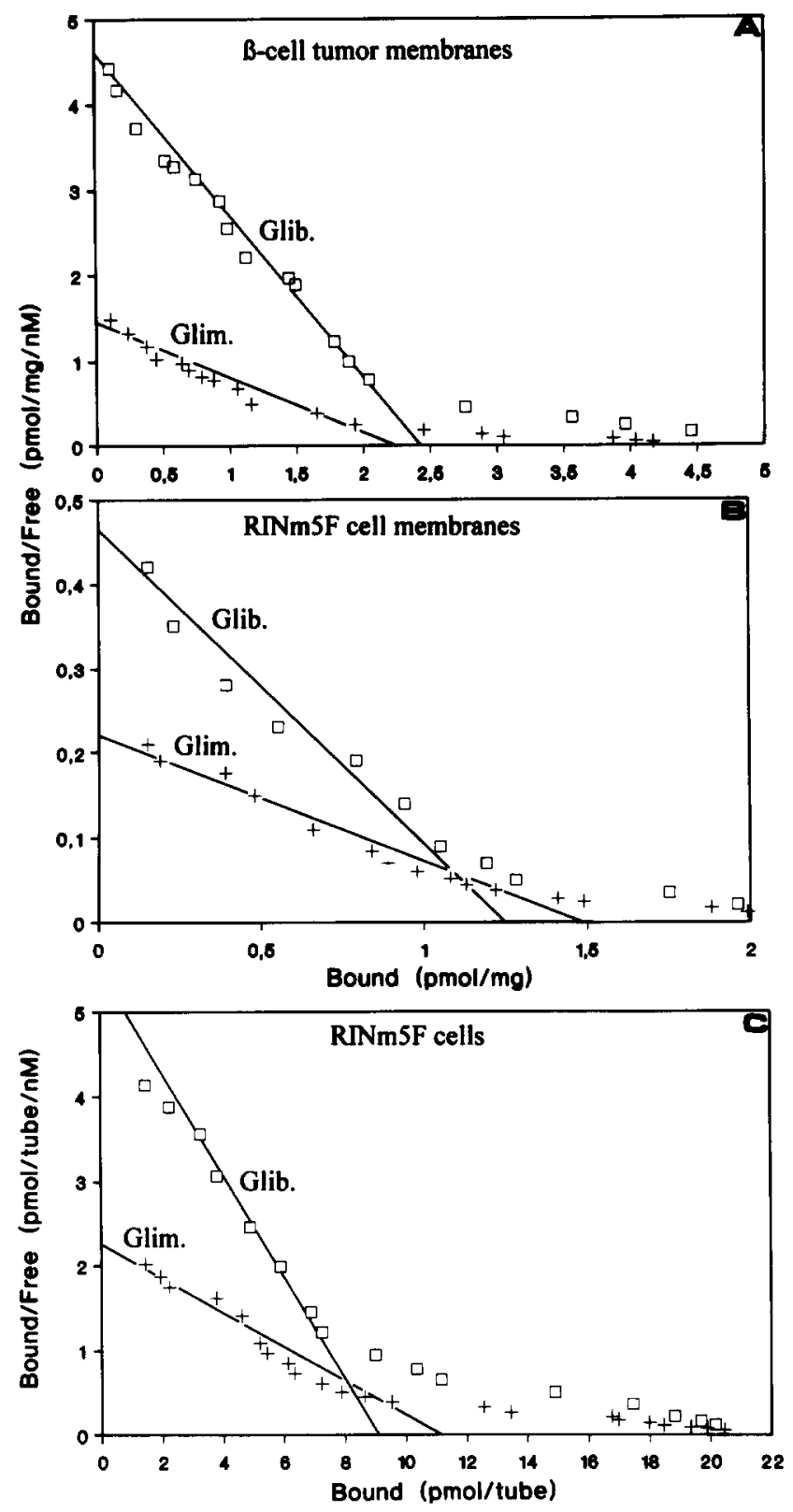

Fig. 1. Scatchard plot analysis of $\left[{ }^{3} \mathrm{H}\right]$ glimepiride and $\left[{ }^{3} \mathrm{H}\right]$ glibenclamide binding. $100 \mu \mathrm{g}$ of $\beta$-cell tumor membranes (Panel A) or $200 \mu \mathrm{g}$ of RINm5F cell membranes (Panel B) or $1.5 \cdot 10^{6}$ RINm5F cells (Panel C) were incubated $\left(60 \mathrm{~min}, 25^{\circ} \mathrm{C}\right.$ for membranes or $4^{\circ} \mathrm{C}$ for cells) with $0.1-20 \mathrm{nM}\left[{ }^{3} \mathrm{H}\right]$ glimepiride $(+)$ or $\left[{ }^{3} \mathrm{H}\right]$ glibenclamide $(\square)$ in the absence (total binding) or presence (non-specific binding) of $2 \mu \mathrm{M}$ unlabeled glimepiride and glibenclamide, respectively, and then rapidly filtered. Specific glimepirideand glibenclamide-binding was determined by subtracting nonspecific binding from total binding. The means of at least 12 independent determinations using three different membrane (cell) preparations were used for calculation of the Scatchard plots. The parameters of the Scatchard analysis are given in Table 1. 
binding or periods indicated for kinetic studies) with $0.1-20 \mathrm{nM}\left[{ }^{3} \mathrm{H}\right]$ glimepiride or $\left[{ }^{3} \mathrm{H}\right]$ glibenclamide at a density of $4 \cdot 10^{6}$ cells per $0.5 \mathrm{ml}$ assay volume. The incubation mixtures were rapidly filtered through Whatman GF/C filters soaked in ice-cold buffer under reduced pressure. Filtration and washing took less than $30 \mathrm{~s}$. The filters were washed with $3 \times 6 \mathrm{ml}$ of ice-cold buffer containing $100 \mu \mathrm{M}$ PMSF, $0.5 \mu \mathrm{g} / \mathrm{ml}$ leupeptin, $0.75 \mu \mathrm{g} / \mathrm{ml}$ pepstatin, $1 \mu \mathrm{g} / \mathrm{ml}$ aprotinin, $50 \mu \mathrm{g}$ antipain dihydrochloride, $20 \mu \mathrm{g} / \mathrm{ml} \mathrm{E}-64$, dried, placed in $10 \mathrm{ml}$ of ACSII scintillation cocktail and counted for radioactivity. Non-specific binding was determined in the presence of $1 \mu \mathrm{M}$ unlabeled ligand.

Kinetic studies. For studying the association kinetics, the binding reactions (incubation conditions see above) were started by addition of radiolabeled ligand and terminated after the indicated periods by rapid filtration. For studying the dissociation kinetics, displacements of radiolabeled ligand bound at equilibrium ( 60 min incubation) were initiated by addition of unlabeled drug (final concn. $1 \mu \mathrm{M}$ ) and terminated after the indicated periods. For termination, the incubation mixtures were rapidly chilled to $2-4^{\circ} \mathrm{C}$ by placing the assay tubes in a solid $\mathrm{CO}_{2} /$ methanol bath for $1 \mathrm{~s}$ immedi- ately prior to filtration in a filtration apparatus located in a cooled bench.

Miscellaneous. Protein was determined with the Amido black staining method (Popov et al. [25]) using BSA as standard.

\section{Results}

\subsection{Glimepiride exhibits lower binding affinity to $\beta$-cell membranes than glibenclamide}

Specific binding of sulfonylurea drugs to isolated $\beta$-cell tumor membranes, HIT T15 and RINm5F cell membranes has been attributed to high $\left(K_{\mathrm{d}}=0.1-1\right.$ $\mathrm{nM})$ and low $\left(K_{\mathrm{d}}=100-400 \mathrm{nM}\right)$ affinity binding sites $[5,6,13-15,17,19,26,27]$. The free plasma glibenclamide levels effective in insulin secretion (low nanomolar range) and the drug concentration required for halfmaximal stimulation of insulin release $(\sim 0.5 \mathrm{nM})$ from pancreatic islets [16] and insulin-secreting cell lines $[5,14]$ point to the high-affinity binding site as the only functional receptor, the occupancy of which ultimately leads to insulin secretion. The difference in the hypo-

Table 1

Summary of sulfonylurea receptor binding data

\begin{tabular}{|c|c|c|c|c|c|c|}
\hline \multirow[t]{2}{*}{ Parameter } & \multirow[t]{2}{*}{ Source of receptor } & \multirow[t]{2}{*}{ Solub. } & \multicolumn{2}{|c|}{ Glimepiride } & \multicolumn{2}{|c|}{ Glibenclamide } \\
\hline & & & \multicolumn{2}{|c|}{ (value \pm S.E.) } & \multicolumn{2}{|c|}{ (value \pm S.E.) } \\
\hline$\overline{K_{\mathrm{d}}}(\mathrm{nM})$ & $\beta$-cell tumor memb. & & 1.5 & 0.3 & 0.5 & 0.1 \\
\hline$K_{\mathrm{d}}(\mathrm{nM})$ & $\beta$-cell tumor memb. & + & 0.6 & 0.1 & 0.5 & 0.3 \\
\hline$B_{\max }(\mathrm{pmol} / \mathrm{mg})$ & $\beta$-cell tumor memb. & & 2.3 & 0.7 & 2.4 & 0.8 \\
\hline$k_{\text {off }}\left(\min ^{-1}\right)$ & $\beta$-cell tumor memb. & & 3.30 & 0.28 & 0.38 & 0.06 \\
\hline$k_{\text {off }}\left(\min ^{-1}\right)$ & $\beta$-cell tumor memb. & + & 0.75 & 0.10 & 0.32 & 0.08 \\
\hline$k_{\mathrm{on}}\left(\min ^{-1} \mathrm{nM}^{-1}\right)$ & $\beta$-cell tumor memb. & & 1.78 & 0.34 & 0.86 & 0.09 \\
\hline$k_{\text {on }}\left(\min ^{-1} \mathrm{nM}^{-1}\right)$ & $\beta$-cell tumor memb. & + & 1.28 & 0.43 & 0.82 & 0.21 \\
\hline$k_{\text {off }} / k_{\text {on }}(\mathrm{nM})$ & $\beta$-cell tumor memb. & & 1.9 & 0.5 & 0.4 & 0.2 \\
\hline$k_{\text {off }} / k_{\text {on }}(\mathrm{nM})$ & $\beta$-cell tumor memb. & + & 0.6 & 0.1 & 0.4 & 0.1 \\
\hline $\mathrm{IC}_{50}$ glib. (nM) & $\beta$-cell tumor memb. & & 40.3 & 4.1 & 12.1 & 3.0 \\
\hline$K_{\mathrm{i}}$ glib. (nM) & $\beta$-cell tumor memb. & & 8.1 & 1.7 & 2.4 & 0.6 \\
\hline $\mathrm{IC}_{50} \operatorname{glim} .(\mathrm{nM})$ & $\beta$-cell tumor memb. & & 15.5 & 3.5 & 5.2 & 0.8 \\
\hline$K_{\mathrm{i}} \operatorname{glim} .(\mathrm{nM})$ & $\beta$-cell tumor memb. & & 6.6 & 1.1 & 2.3 & 0.7 \\
\hline $\mathrm{IC}_{50} \operatorname{glim} .(\mathrm{nM})$ & $\beta$-cell tumor memb. & + & 7.1 & 0.6 & 5.1 & 1.7 \\
\hline$K_{\mathrm{d}}(\mathrm{nM})$ & RINm5F cell memb. & & 6.8 & 1.2 & 2.7 & 0.3 \\
\hline$B_{\max }(\mathrm{pmol} / \mathrm{mg})$ & RINm5F cell memb. & & 1.5 & 0.4 & 1.3 & 0.3 \\
\hline$k_{\text {off }}\left(\min ^{-1}\right)$ & RINm5F cell memb. & & 2.14 & 0.41 & 0.25 & 0.09 \\
\hline$k_{\mathrm{on}}\left(\min ^{-1} \mathrm{nM}^{-1}\right)$ & RINm5F cell memb. & & 0.49 & 0.14 & 0.17 & 0.08 \\
\hline$k_{\text {off }} / k_{\text {on }}(\mathrm{nM})$ & RINm5F cell memb. & & 4.4 & 1.2 & 1.5 & 0.3 \\
\hline $\mathrm{IC}_{50}$ glib. (nM) & RINm5F cell memb. & & 89.5 & 54.3 & 26.7 & 9.8 \\
\hline$K_{\mathrm{i}}$ glib. (nM) & RINm5F cell memb. & & 51.4 & 28.3 & 15.3 & 4.3 \\
\hline $\mathrm{IC}_{50} \operatorname{glim} .(\mathrm{nM})$ & RINm5F cell memb. & & 31.6 & 12.6 & 10.3 & 8.9 \\
\hline$K_{\mathrm{i}} \operatorname{glim} .(\mathrm{nM})$ & RINm5F cell memb. & & 24.4 & 9.7 & 8.0 & 2.5 \\
\hline $\mathrm{IC}_{50}$ glim. (nM) & RINm5F cell memb. & + & 8.2 & 2.5 & 7.5 & 1.3 \\
\hline$K_{\mathrm{d}}(\mathrm{nM})$ & RINm5F cells & & 4.7 & 1.0 & 1.7 & 0.5 \\
\hline$B_{\max }\left(\mathrm{pmol} / 4 \cdot 10^{6}\right.$ cells $)$ & RINm5F cells & & 11.0 & 1.3 & 9.4 & 2.7 \\
\hline$k_{\text {off }}\left(\min ^{-1}\right)$ & RINm5F cells & & 3.61 & 0.73 & 0.43 & 0.11 \\
\hline$k_{\mathrm{on}}\left(\min ^{-1} \mathrm{nM}^{-1}\right)$ & RINm5F cells & & 0.64 & 0.21 & 0.22 & 0.07 \\
\hline$k_{\text {off }} / k_{\text {on }}(\mathrm{nM})$ & RINm5F cells & & 5.6 & 2.1 & 2.0 & 0.5 \\
\hline
\end{tabular}


glycemic efficacy between glimepiride and glibenclamide prompted us to study its binding affinity to isolated membranes from $\beta$-cell tumors and RINm5F cells as well as to RINm5F cells by equilibrium binding using a filtration assay.

Specific binding of $\left[{ }^{3} \mathrm{H}\right]$ glimepiride and $\left[{ }^{3} \mathrm{H}\right]$ glibenclamide to $\beta$-cell tumor and RINm5F cell membranes at room temperature reached equilibrium within $50-60$ min (see below) and was protein-dependent (0.05-0.3 $\mathrm{mg} \beta$-cell tumor membrane protein per $\mathrm{ml}$ or $0.1-0.5$ mg RINm5F cell membrane protein) in a linear fashion (data not shown). Specific binding of $\left[{ }^{3} \mathrm{H}\right]$-glimepiride and $\left[{ }^{3} \mathrm{H}\right]$ glibenclamide to RINm5F cells at $4^{\circ} \mathrm{C}$ was dependent on the cell number $\left((0.2-5) \cdot 10^{6}\right.$ cells $\left./ \mathrm{ml}\right)$. Thus, $0.1-0.2 \mathrm{mg}$ protein $/ \mathrm{ml}$ and $1.5 \cdot 10^{6}$ cells $/ \mathrm{ml}$ used in the present study were well within the linear range of the binding curves. Specific binding of $\left[{ }^{3} \mathrm{H}\right]$ glimepiride and $\left[{ }^{3} \mathrm{H}\right]$ glibenclamide to $100 \mu \mathrm{g}$ of $\beta$-cell tumor and $200 \mu \mathrm{g}$ of RINm5F cell membrane protein at room temperature or to $1.5 \cdot 10^{6} \mathrm{RINm} 5 \mathrm{~F}$ cells at $4^{\circ} \mathrm{C}$ increased from 0.1 to $10 \mathrm{nM}$ radioligand and exhibited saturability (data not shown). Displacement of $\left[{ }^{3} \mathrm{H}\right]$ glimepiride- and $\left[{ }^{3} \mathrm{H}\right]$ glibenclamide-binding with excess of the corresponding unlabeled compound revealed a moderate rise of non-specific binding with increasing ligand concentration which, however, never exceeded $20 \%$ (membranes) and $30 \%$ (RINm5F cells) of the specific binding. Glimepiride and glibenclamide are characterized by comparable non-specific binding to $\beta$-cell membranes as well as to RINm5F cells.

Scatchard plots derived from saturation experiments were curve-linear suggesting the existence of both highand low-affinity binding sites in $\beta$-cell tumor membranes, RINm5F cell membranes and RINm5F cells (Fig. 1, Panels A-C). The $K_{d}$ values calculated under steady state conditions for the high-affinity binding
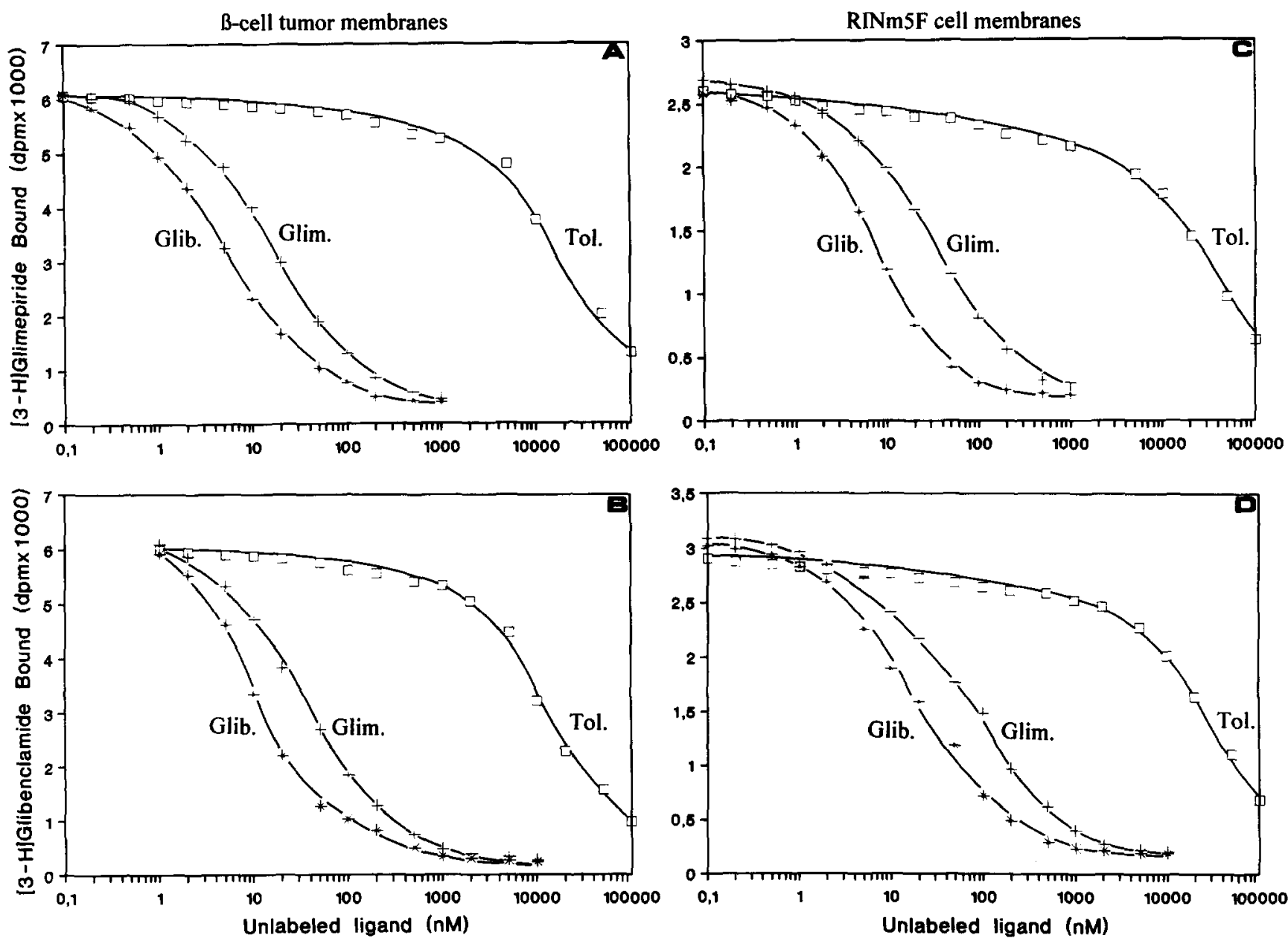

Fig. 2. Displacement of $\left[{ }^{3} \mathrm{H}\right]$ glimepiride and $\left[{ }^{3} \mathrm{H}\right]$ glibenclamide binding to $\beta$-cell membranes by sulfonylurea drugs. $100 \mu \mathrm{g}$ of $\beta$-cell tumor (Panels A and B) or $200 \mu \mathrm{g}$ of RINm5F cell membranes (Panels $\mathrm{C}$ and D) were incubated $\left(45 \mathrm{~min}, 25^{\circ} \mathrm{C}\right.$ ) with $2 \mathrm{nM}\left[{ }^{3} \mathrm{H}\right] \mathrm{glimepiride}(\mathrm{Panels} \mathrm{A}$ and $C$ ) or $\left[{ }^{3} \mathrm{H}\right]$ glibenclamide (Panels $B$ and $\left.D\right)$ in the presence of the indicated concentrations of unlabeled displacing drug ( ${ }^{*}$, glibenclamide; + , glimepiride; $\square$, tolbutamide) (total binding) or of $2 \mu \mathrm{M}$ unlabeled glimepiride and glibenclamide, respectively, (non-specific binding). The membranes were filtered and counted for radioactivity. Specific binding (dpm) was calculated as difference between total and non-specific binding. Each point represents the mean of 10 different determinations using two independent membrane preparations. The $\mathrm{IC}_{50}$ and $K_{\mathrm{i}}$ values for homologous and heterologous inhibiton of $\left[{ }^{3} \mathrm{H}\right]$ glimepiride and $\left[{ }^{3} \mathrm{H}\right] \mathrm{glibenclamide}$ binding are given in Table 1 . 
sites are given in Table 1. Thus, glimepiride is characterized by a 2.5 -3-fold lower affinity to rat $\beta$-cell tumor and RINm5F cell membranes as well as RINm5F cells compared to glibenclamide. The number of highaffinity binding sites is very similar for glimepiride and glibenclamide, but about 3-4-fold higher for $\beta$-cell tumor membranes compared to RINm5F membranes and RINm5F cells (Table 1).

\subsection{Displacement of ligand binding confirms the ranking order of affinity for glimepiride and glibenclamide}

To confirm the difference in affinity between glimepiride and glibenclamide, competition binding ex- periments were performed. Displacement curves of $\left[{ }^{3} \mathrm{H}\right]$ glimepiride- and $\left[{ }^{3} \mathrm{H}\right]$ glibenclamide-binding (Fig. 2) were used to calculate the concentrations for halfmaximal inhibition ( $\mathrm{IC}_{50}$ values) (Table 1). As expected from the lower affinity of glimepiride, this drug was less potent in displacing bound $\left[{ }^{3} \mathrm{H}\right]$ glimepiride (Panels $A$ and $C$ ) and $\left[{ }^{3} \mathrm{H}\right]$ glibenclamide (Panels $B$ and $D$ ) from $\beta$-cell tumor (Panels $A$ and $B$ ) and RINm5F (Panels $\mathrm{C}$ and D) cell membranes than glibenclamide. 3.5-4-Fold higher concentrations of glimepiride and about 1000 -fold higher concentrations of tolbutamide were necessary to achieve half-maximal inhibition of binding. This relationship emphasizes the specificity of sulfonylurea binding to $\beta$-cell membranes.

\section{B-cell tumor membranes}
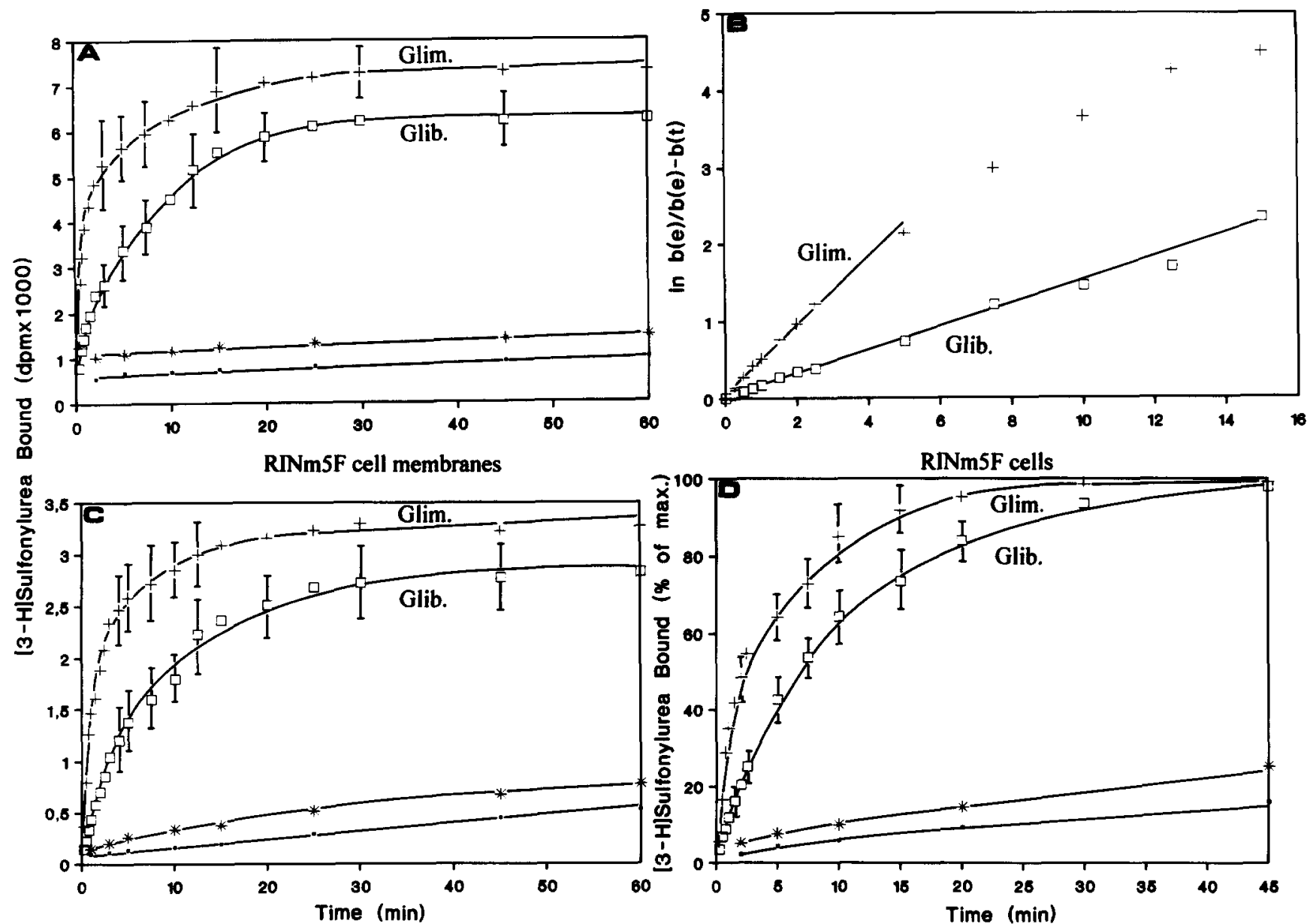

Fig. 3. Association kinetics of $\left[{ }^{3} \mathrm{H}\right]$ sulfonylurea binding to $\beta$-cell membranes and $\beta$-cells. $100 \mu \mathrm{g}$ of $\beta$-cell tumor membranes (Panels $\mathrm{A}$ and $\mathrm{B}$ ) or $200 \mu \mathrm{g}$ of RINm5F cell membranes (Panel C) or $1.5 \cdot 10^{6} \mathrm{RINm5F}$ cells (Panel D) were incubated (various periods, $25^{\circ} \mathrm{C}$ for membranes or $4^{\circ} \mathrm{C}$ for cells) with $2 \mathrm{nM}\left[{ }^{3} \mathrm{H}\right] \mathrm{glimepiride}\left(+,{ }^{*}\right)$ and $\left[{ }^{3} \mathrm{H}\right] \mathrm{glibenclamide}(\square, \bullet)$ in the absence (total binding) or presence (non-specific binding) of 2 $\mu \mathrm{M}$ unlabeled glimepiride $\left(^{*}\right)$ and glibenclamide $(\bullet)$, immediately chilled to $0^{\circ} \mathrm{C}$ and then rapidly filtered. Specific glimepiride $(+)$ and glibenclamide $(\square)$ binding was calculated by subtracting non-specific binding from total binding. The amount of radiolabeled sulfonylurea bound to RINm5F cells after 60 min of incubation (equilibrium conditions) was set at $100 \%$ (Panel D). Each point represents the mean \pm S.D. of 15 (8) different determinations using 5 (4) independent membrane (cell) preparations. Panel B displays the logarithmic plots of the ratio of $\left[{ }^{3} \mathrm{H}\right]$ glimepiride $(+)$ or $\left[{ }^{3} \mathrm{H}\right] \mathrm{glibenclamide}(\square)$ bound under equilibrium conditions after 45 min incubation $(b(\mathrm{e}))$ to the difference between the sulfonylurea bound at equilibrium $(b(e))$ and at any time point during incubation $(b(t))$ versus incubation time $(t)$. The calculated association rate constants ( $k_{\text {on }}$ values) are given in Table 1. 
3.3. Glimepiride exhibits higher exchange rates for binding to $\beta$-cell membranes than glibenclamide

Next we asked the question whether the reduced affinity of glimepiride is based on lower association and/or higher dissociation rates of binding compared to glibenclamide. For studying the association kinetics (Fig. 3), $\beta$-cell tumor membranes, RINm5F cell membranes and RINm5F cells were incubated with $\left[{ }^{3} \mathrm{H}\right]$ glimepiride and $\left[{ }^{3} \mathrm{H}\right]$ glibenclamide and, after the periods indicated, immediately chilled, filtered and counted for radioactivity. For studying the dissociation kinetics (Fig. 4), the membranes and cells were preloaded with submaximal concentrations of $\left[{ }^{3} \mathrm{H}\right]$ sulfonylureas for $60 \mathrm{~min}$ at $25^{\circ} \mathrm{C}$ and $4^{\circ} \mathrm{C}$, respectively.
Displacement of radiolabel was initiated by addition of 1000 -fold molar excess of unlabelel ligand. $\left[{ }^{3} \mathrm{H}\right]$ Glimepiride or $\left[{ }^{3} \mathrm{H}\right]$ glibenclamide remaining bound after the indicated periods was determined by rapid filtration.

The time-courses revealed that glimepiride clearly associated with (Fig. 3) and dissociated from (Fig. 4) $\beta$-cell tumor cell membranes (Panel A), RINm5F cell membranes (Panel C) and RINm5F cells (Panel D) more rapidly than glibenclamide (half-life times for association $2.5-3 \mathrm{~min}$ vs. $6-10 \mathrm{~min}$; half-life times for dissociation $2-2.5 \mathrm{~min}$ vs. $10-14 \mathrm{~min}$ ) with only marginal differences between $\beta$-cell tumor membranes, RINm5F cell membranes and RINm5F cells. We studied whether the higher exchange rate of glimepiride as revealed by the binding kinetics can

B-cell tumor membranes
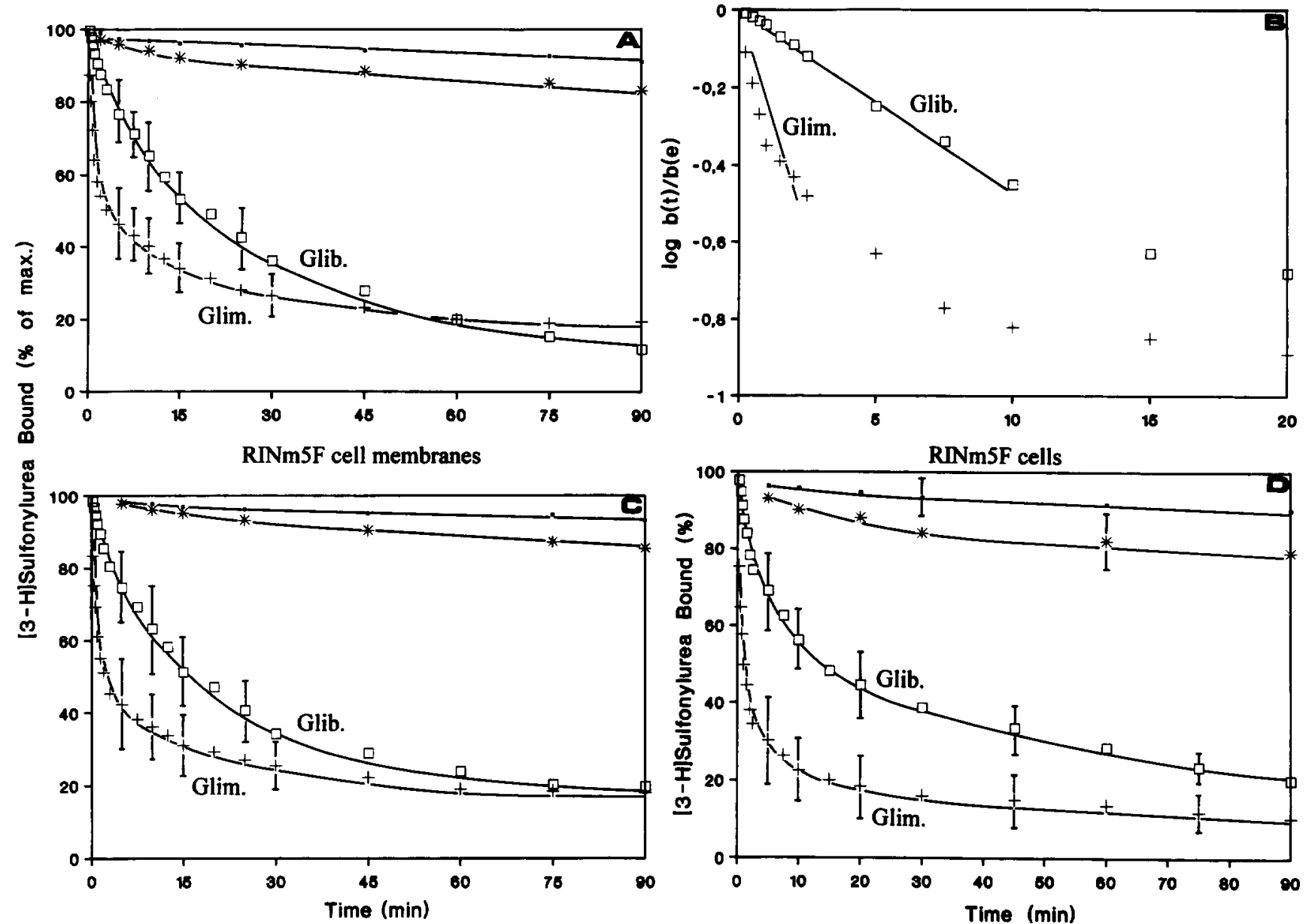

Fig. 4. Dissociation kinetics of $\left[{ }^{3} \mathrm{H}\right]$ sulfonylurea binding to $\beta$-cell membranes and $\beta$-cells. $100 \mu \mathrm{g}$ of $\beta$-cell tumor membranes (Panels $\mathrm{A}$ and $\mathrm{B}$ ) or $200 \mu \mathrm{g}$ of RINm5F cell membranes (Panel C) or $1.5 \cdot 10^{6} \mathrm{RINm5F}$ cells (Panel D) were incubated $\left(45 \mathrm{~min}, 25^{\circ} \mathrm{C}\right.$ for membranes or $4^{\circ} \mathrm{C}$ for cells) with $2 \mathrm{nM}\left[{ }^{3} \mathrm{H}\right] \mathrm{glimepiride}(+, \bullet)$ or $\left[{ }^{3} \mathrm{H}\right] \mathrm{glibenclamide}\left(\square,{ }^{*}\right)$ in the absence (total binding) or presence (non-specific binding) of $2 \mu \mathrm{M}$ unlabeled sulfonylurea. At zero time, dissociation was induced by addition of unlabeled glimepiride and glibenclamide (final concn. $2 \mu \mathrm{M}$ ), respectively, to one half of each sample $(\square,+)$. The other half was left and incubated in parallel as a control $\left(\bullet,{ }^{*}\right)$. After the time periods indicated, aliquots were immediately chilled, filtered and counted for radioactivity. Specific binding calculated as difference between the total and non-specific binding is given as percentage of specific binding at zero time $(=100 \%)$. Each point represents the mean \pm S.D. of 12 (9) independent determinations using 4 (3) different membrane (cell) preparations. Panel B displays the logarithmic plot of the ratio of sulfonylurea bound at any time point $(b(t))$ to bound at equilibrium $(b(\mathrm{e}))$ versus incubation time $(t)$. The calculated dissociation rate constants $\left(k_{\text {off }}\right.$ values) are given in Table 1. 
account for its higher dissociation constant compared to glibenclamide as measured by equilibrium binding. For this, the $K_{\mathrm{d}}$ values were calculated as ratio between the dissociation and association rate constants. For calculation of the $k_{\text {on }}$ rate, the association reaction was treated as being pseudo-first order. Fig. 3, Panel B displays the logarithmic plots of the ratio of ligand concentration bound to $\beta$-cell tumor membranes (not shown for RINm5F cell membranes and RINm5F cells) under equilibrium conditions to the difference of the ligand concentration bound under equilibrium conditions and bound at each time point $(t)$ versus time. Fig. 4 , Panel B displays the $k_{\text {off }}$ rates as the logarithmic plot of the ratio of ligand concentration bound at time $(t)$ to that bound initially under equilibrium conditions versus time (not shown for RINm5F cell membranes and RINm5F cells). As expected from the respective half-life times, 2.5-3-fold higher association and 7-9fold higher dissociation velocities were calculated for glimepiride compared to glibenclamide. The $k_{\text {off }} / k_{\text {on }}$ ratios (Table 1) of glimepiride and glibenclamide for binding to $\beta$-cell tumor membranes, RINm5F cell membranes and RINm5F cells are well in line with their $K_{\mathrm{d}}$ values as determined by equilibrium binding. Thus, the lower binding affinity of glimepiride is explained by its binding kinetics. The logarithmic association and dissociation plots displayed non-linear curves. The biphasic nature of the time-courses which was more pronounced for glimepiride than for glibenclamide points to the occurrence of either heterogenous (high- and low-affinity) sulfonylurea binding sites or to cooperativity between two (or more) similar binding sites rather than to a bimolecular reaction involving only one type of binding centre (see Weiland et al. [28] for a discussion of binding kinetics).

\subsection{Solubilization of $\beta$-cell membranes alters the binding characteristics of the glimepiride-binding sites}

So far it is unknown from which side of the $\beta$-cell plasma membrane sulfonylureas gain access to their high-affinity binding sites and whether the drugs interact with the receptor from the aqueous environment or from the lipid bilayer after lateral movement in the plane of the membrane. The accessibility of the receptor for sulfonylureas may determine in part their binding characteristics and explain differences herein between drugs of different lipophilicity as is the case for glimepiride and glibenclamide. Therefore, we finally studied the influence of the membrane environment on the $K_{\mathrm{d}}$ values and kinetic binding parameters of glimepiride and glibenclamide. To allow measurement of specific $\left[{ }^{3} \mathrm{H}\right]$ sulfonylurea binding to detergentsolubilized membrane proteins, the filtration assay was modified by precipitation of the total incubation mixtures with PEG in the cold prior to filtration over
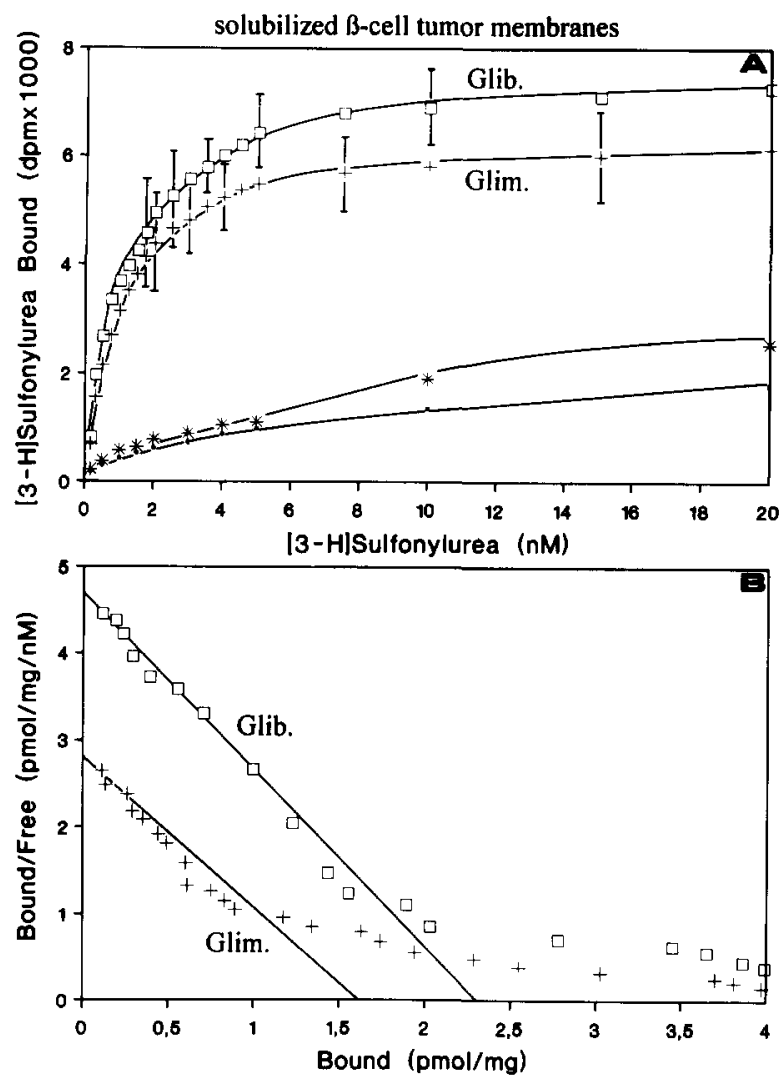

Fig. 5. Scatchard plot analysis of $\left[{ }^{3} \mathrm{H}\right]$ sulfonylurea binding to solubilized $\beta$-cell tumor membrane proteins. The experiments were carried out as described in the legend to Fig. 1 but using $100 \mu \mathrm{g}$ of digitonin-solubilized $\beta$-cell tumor membrane proteins and precipitation of the solubilized proteins with poly(ethylene glycol) prior filtration. Panel A, saturation curves of specific binding; Panel B, Scatchard plot analysis.

nitrocellulose filters. The precipitates retained on the filter were washed with ice-cold PEG-containing washing solution. The protein dependence of specific $\left[{ }^{3} \mathrm{H}\right]$ glimepiride and $\left[{ }^{3} \mathrm{H}\right]$ glibenclamide binding to solubilized $\beta$-cell tumor membrane proteins, comparable maximal binding capacities before and after solubilization and low (15-20\%) unspecific binding (data not shown) demonstrated almost quantitative recovery of $\left[{ }^{3} \mathrm{H}\right]$ sulfonylurea specifically bound to solubilized $\beta$-cell tumor membrane proteins using the modified procedure. In contrast to $\beta$-cell tumor membranes, RINm5F cell membranes and RINm5F cells, low-affinity binding sites for both sulfonylureas were barely detectable upon solubilization of $\beta$-cell tumor membranes. Similar observations were made previously by Niki et al. [29] for HIT T15 cell membranes.

The Scatchard plot analysis shows that solubilization by digitonin did only marginally affect the binding parameters for glibenclamide (Fig. 5 compared to Fig. 1). In contrast, glimepiride exhibited a 2.5-3-fold higher affinity to solubilized $\beta$-cell tumor membrane proteins compared to membranes. This was also reflected in the 
$K_{\mathrm{d}}$ values calculated as $k_{\text {off }} / k_{\text {on }}$ ratios from association and dissociation experiments (Table 1). This rise in affinity upon solubilization was based mainly on the $\sim 4.5$-fold reduction of the $k_{\text {off }}$ rate constant for glimepiride (Fig. 6, Panels A and B) whereas the $k_{\text {on }}$ rate constant decreased only $\sim 0.7$-fold (Fig. 6, Panels $\mathrm{C}$ and $\mathrm{D})$ compared to the value for membranes. In marked contrast, the $k_{\text {off }}$ and $k_{\text {on }}$ rate constants for glibenclamide were only marginally affected upon solubilization of $\beta$-cell membranes (Fig. 6 and Table 1). Consequently, the affinity of glimepiride to solubilized $\beta$-cell membranes was only slightly lower than of glibenclamide. This was corroborated by the lower concentrations of glimepiride but not of glibenclamide which were required for displacement of $\left[{ }^{3} \mathrm{H}\right]$ glimepiride bound to solubilized $\beta$-cell tumor (Fig. 7, Panel A) and RINm5F cell (Panel B) membrane proteins compared to the respective membranes (see Fig. 2). As a result, the $\mathrm{IC}_{50}$ values of glimepiride for inhibition of $\left[{ }^{3} \mathrm{H}\right]$ glimepiride binding to the solubilized receptor de- creased up to the values of glibenclamide for the solubilized as well as membrane-embedded receptor (Table 1).

\section{Discussion}

The present data strongly suggest that the lower binding affinity of glimepiride to $\beta$-cell membranes relies at least in part on the membrane environment of the sulfonylurea receptor. However, this does not exclude the possibility that glimepiride and glibenclamide actually bind to different receptor proteins which display different binding characteristics when embedded within the $\beta$-cell membrane. Elucidation of this point will require identification of the binding proteins, e.g., by means of photoaffinity labeling (Kramer et al. [30]; see accompanying paper [31]).

The physiological relevance of the higher exchange rate (i.e., higher association and dissociation velocities)

solubilized B-cell tumor membranes
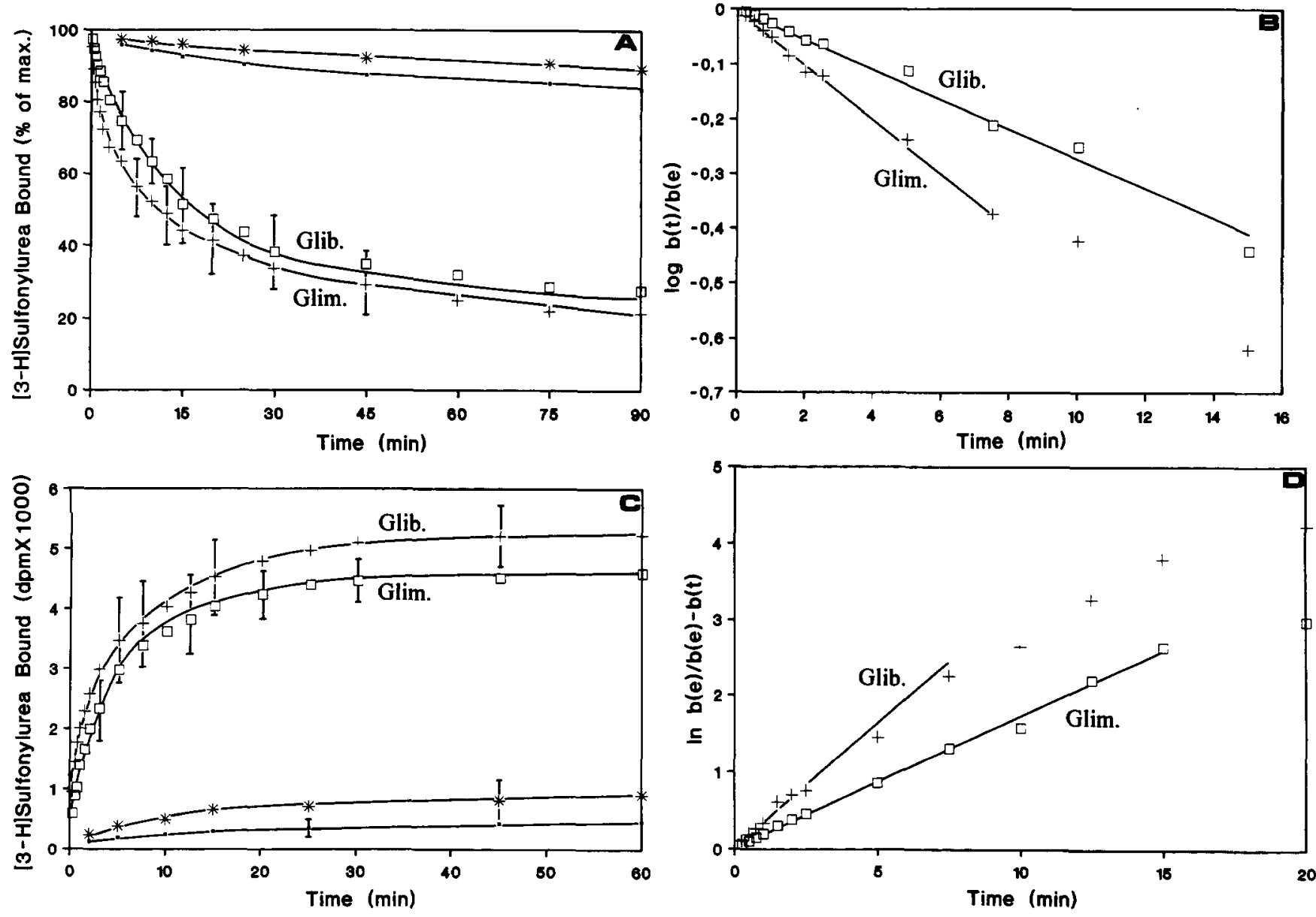

Fig. 6. Association and dissociation kinetics of $\left[{ }^{3} \mathrm{H}\right]$ sulfonylurea binding to solubilized $\beta$-cell tumor membrane proteins. The experiments were carried out as described in the legends to Figs. 4 and 5 but using $100 \mu \mathrm{g}$ of digitonin-solubilized $\beta$-cell tumor membranes and precipitation of the solubilized proteins prior to filtration. Panel A, dissociation curves of specific binding; Panel $\mathrm{B}$, logarithmic plots of the dissociation reactions; Panel C, association curves of specific binding; Panel D, logarithmic plots of the association reactions. 


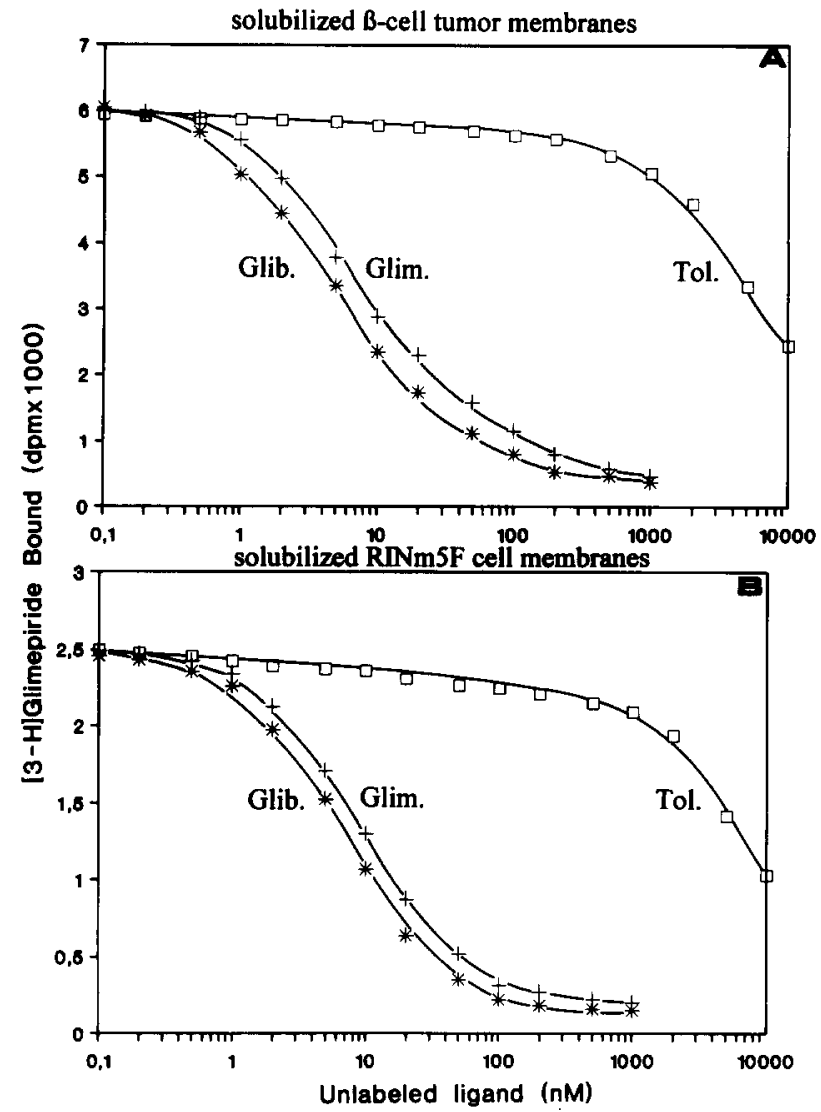

Fig. 7. Displacement of $\left[{ }^{3} \mathrm{H}\right]$ glimepiride binding to solubilized $\beta$-cell membrane proteins by sulfonylurea drugs. The experiments were carried out as described in the legend to Fig. 2 but using $100 \mu \mathrm{g}$ of solubilized $\beta$-cell tumor (Panel A) or $200 \mu \mathrm{g}$ of RINm5F cell (Panel B) membrane proteins, respectively, and precipitation of the solubilized proteins with poly(ethylene glycol) prior to filtration.

of glimepiride with its receptor protein as well as of its lower binding affinity compared to glibenclamide remains a matter of speculation. (i) The initial decrease of the blood sugar levels in dogs, rats and rabbits is more pronounced after oral and intravenous administration of clear sodium salt solutions of glimepiride compared to, glibenclamide [21]. The rapid-onset blood glucose lowering activity of glimepiride may be due to a more rapid direct insulinotropic effect upon the islet of Langerhans. In agreement with this hypothesis, it was found that in the perifused rat pancreatic islets and in the isolated perfused rat pancreas, glimepiride released insulin more rapidly and more effectively than glibenclamide (Geisen, K., unpublished results). This may be related to the 3 -fold higher $k_{\text {on }}$ rate of glimepiride binding to $\beta$-cell membranes. However, with respect to the blood sugar lowering profile, it is difficult to dissect differences in kinetic binding parameters from different pharmacokinetic behaviour of the two drugs. (ii) The prolonged decline of plasma glucose levels provoked by a single oral dose of glimepiride compared to glibenclamide in dogs and rabbits (Geisen
[21]) may be explained by the 3 -fold higher exchange rate of glimepiride bound to the sulfonylurea receptor if desensitization of the insulin releasing mechanism is induced by occupancy of the sulfonylurea receptor with a drug (exhibiting a lower exchange rate). Desensitization of receptor mediated processes by permanent binding of the ligand to its receptor involving distinct molecular mechanisms is well established for several hormone signaling pathways, i.e., $\beta$-adrenergic receptors (for a review, see Benovic et al. [32]). In this respect, it is interesting that internalization of glibenclamide has been reported for HIT T15 cells (Carpentier et al. [33]). If this based on endocytosis of the sulfonylurea receptor when occupied by the ligand, it may represent a mechanism for desensitization by down regulation of the number of sulfonylurea receptors at the cell surface which will be more pronounced for sulfonylureas with lower exchange rate. However, the long term hypoglycemic activity of sulfonylureas, in general, and of glimepiride, in special, may involve so-called extra-pancreatic sites of action, in addition (Kolterman et al. [34]; Müller et al. [35]; for a review, see Gerich [36]). (iii) The higher $K_{d}$ value of glimepiride compared to glibenclamide may be responsible for the lower total decline of the blood sugar in the dog (Geisen [21]). Clearly, these features would represent significant therapeutical benefits for NIDDM patients.

\section{Acknowledgements}

The authors are grateful to S. Hirluksch and E.-M. Wetekam for excellent technical assistance in preparing the cell culture.

\section{References}

[1] Yalow, R.S., Black, H., Villazon, M. and Berson, S. (1960) Diabetes 9, 356-362.

[2] Boyd III, A.E. (1988) Diabetes 37, 847-850.

[3] Boyd III, A.E., Aguilar-Bryan, L., Bryan, J., Kunze, D.L., Moss, L., Nelson, D.A., Rajan, A.S., Raef, H., Xiang, H. and Yaney, G.C. (1991) Recent Prog. Horm. Res. 47, 299-317.

[4] Sturgess, N.C., Ashcroft, M.L.J., Cook, D.L. and Hales, C.N. (1985) Lancet 2, 474-475.

[5] Schmid-Antomarchi, H., De Weille, J., Fosset, M. and Lazdunski, M. (1987) J. Biol. Chem. 262, 15840-15844.

[6] Niki, I., Kelly, R.P., Ashcroft, S.J.H. and Ashcroft, F.M. (1989) Pflügers Arch. 415, 47-55.

[7] Ashcroft, F.M., Harrison, D.E. and Ashcroft, S.J.H. (1984) Nature 312, 446-448.

[8] Gylfe, E., Hellman, B., Sehlin, J. and Täljedal, I.-B. (1984) Experientia 40, 1126-1134.

[9] Nelson, T.Y., Gaines, K.L., Rajan, A.S., Berg, M. and Boyd III, A.E. (1987) J. Biol. Chem. 262, 2608-2612.

[10] Boyd III, A.E. (1992) J. Cell. Biochem. 48, 234-241.

[11] Ashcroft, S.J.H. and Ashcroft, F.M. (1993) Biochim. Biophys. Acta 1175, 45-59. 
[12] Kaubisch, N., Hammer, R., Wollheim, C., Renold, A.E. and Offord, R.E. (1982) Biochem. Pharmacol. 31, 1171-1174.

[13] Geisen, K., Hitzel, V., Ökonomopulos, R., Pünter, J., Weyer, R. and Summ, H.-D. (1985) Drug. Res. 35, 707-712.

[14] Aguilar-Bryan, L., Nelson, D.A., Vu, Q.A., Humphrey, M.B. and Boyd III, A.E. (1990) J. Biol. Chem. 265, 8218-8224.

[15] Schmid-Antomarchi, H., De Weille, J., Fosset, M. and Lazdunski, M. (1987) Biochem. Biophys. Res. Commun. 146, 21-25.

[16] Panten, U., Burgfeld, J., Goerke, F., Rennicke, M., Schwanstecher, M., Wallasch, A., Zünkler, B.J. and Lenzen, S. (1989) Biochem. Pharmacol. 38, 1217-1229.

[17] Gaines, K.L., Hamilton, S. and Boyd III, A.E. (1988) J. Biol. Chem. 263, 2589-2592.

[18] Niki, I., Ashcroft, F.M. and Ashcroft, S.J.H. (1989) FEBS Lett. $257,361-364$.

[19] Niki, I., Nicks, J.L. and Ashcroft, S.J.H. (1990) Biochem. J. 268, 713-718.

[20] Sugiura, M., Sawada, Y., Yamada, Y., Nakamura, K. and Iga, T. (1992) Xenobiot. Metab. Dispos. 7, 233-241.

[21] Geisen, K. (1988) Drug. Res. 38, 1120-1130.

[22] Chick, W.L., Warren, S., Chute, R.N., Like, N.A., Lauris, V. and Kitchen, K. (1977) Proc. Natl. Acad. Soc. USA 74, 628-632.

[23] Bhathena, S.J., Ole, H.K., Gazdar, A.F., Vovles, N.R., Wilkins, S.D. and Recant, L. (1982) Diabetes 31, 521-531.

[24] Praz, G.A., Halban, P.A., Wollheim, C.B., Blondel, B., Strauss, A.J. and Renold, A.E. (1983) Biochem. J. 210, 345-352.
[25] Popov, N., Schmitt, M., Schulzeck, W. and Matthies, H. (1975) Acta Biol. Med. Germ. 34, 1441-1446.

[26] French, J.F., Riera, L.C., Mullins, U.L. and Sarmiento, J.C. (1991) Eur. J. Pharmacol. Mol. Pharmacol. Sect. 207, 23-28.

[27] Nelson, D.A., Aguilar-Bryan, L. and Bryan, J. (1992) J. Biol. Chem. 267, 14928-14933.

[28] Weiland, G.A. and Molinoff, P.B. (1981) Life Sci. 29, 313-320.

[29] Niki, I., Welsh, M., Berggren, P.-O., Hubbard, P. and Ashcroft, S.J.H. (1991) Biochem. J. 277; 619-624.

[30] Kramer, W., Ökonomopulos, R., Pünter, J. and Summ, H.-D. (1988) FEBS Lett. 229, 355-359.

[31] Kramer, W., Müller, G., Girbig, F., Gutjahr, U., Kowalewski, S., Hartz, D. and Summ, H.-D. (1994) Biochim. Biophys. Acta 1191, 278-290.

[32] Benovic, J.L, Bouvier, M., Caron, M.G. and Lefkowitz, R.J. (1988) Annu. Rev. Cell Biol. 4, 405-428.

[33] Carpentier, J.-L., Sawano, F., Ravazzola, M. and Malaisse, W.J. (1986) Diabetologia 29, 259-261.

[34] Kolterman, O.G., Gray, R.S, Shapiro, G., Scarlett, J.A., Griffin, J. and Olefsky, J.M. (1984) Diabetes 33, 346-354.

[35] Müller, G., Dearey, E.A. and Pünter, J. (1993) Biochem. J. 289 , 509-521.

[36] Gerich, J.E. (1989) N. Engl. J. Med. 321, 1231-1245. 